\title{
Somatic embryos response against iron stress in in-vitro culture condition of East Kalimantan (Indonesia) rice
}

\author{
NURHASANAH", RAMITA, BAMBANG SUPRIYANTO, WIDI SUNARYO \\ Department of Agroecotechnology, Faculty of Agriculture, Mulawarman University. Jl. Pasir Balengkong No.1 Kampus Gunung Kelua, Samarinda \\ 75123, East Kalimantan, Indonesia. Tel.: +62-541-749159, Fax.: +62-541-738341, "email: nurhasanah_2710@yahoo.com.
}

Manuscript received: 2 June 2019. Revision accepted: 24 July 2019.

\begin{abstract}
Nurhasanah, Ramita, Supriyanto B, Sunaryo W. 2019. Somatic embryos response against iron stress in in-vitro culture condition of East Kalimantan (Indonesia) rice. Biodiversitas 20: 2288-2294. Iron toxicity is major abiotic stress that limits rice production in most tropical regions. A high iron concentration will lead to the abnormal growth and development, decreased yield, and even death of the plant. Compared to other recommended treatments to overcome iron toxicity problems, the use of tolerant cultivars is considered the most effective and efficient approach. In this study, the tolerant character against iron stress was developed using East Kalimantan local rice cultivars through somaclonal variation and in vitro selection. The somatic embryos from four indica rice cultivars, Mayas Pancing, Gedagai, Siam, and Serai, were selected in iron-containing media. Five levels of iron concentrations were applied in the

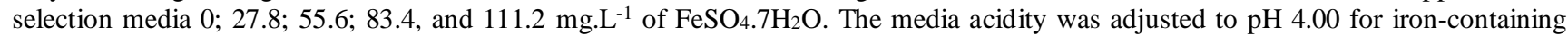
media and 5.8 for the zero iron concentration (without iron). The results showed that the survival ability of embryonic calli (EC) was significantly influenced by the level of iron concentration. The absence of an iron source in the selection media led to lower EC survival. The percentage of EC survival ability was even lower than that of the presence of two folds of normal iron concentration $\left(55.6 \mathrm{mgL}^{-1} \mathrm{of}^{-}\right.$ $\left.\mathrm{FeSO}_{4} .7 \mathrm{H}_{2} \mathrm{O}\right)$. Three and four folds of the normal iron concentration $\left(83.6 \mathrm{mg} . \mathrm{L}^{-1}\right.$ and $\left.111.2 \mathrm{mg} . \mathrm{L}^{-1} \mathrm{FeSO}_{4} .7 \mathrm{H}_{2} \mathrm{O}\right)$ mostly produced the lowest percentage of EC survival for the four local rice cultivars. Mayas Pancing had better tolerance to iron stress and the highest EC survival number compared to other genotypes. The role of genotype was clearly observed in the regeneration ability of EC. Plantlets were only produced on the EC from the Serai Gunung and Siam cultivars.
\end{abstract}

Keywords: East Kalimantan, embryo somatic, in-vitro selection, iron stress, local rice

\section{INTRODUCTION}

Iron $(\mathrm{Fe})$ is an essential micronutrient for living cells. It plays a critical role in respiration and photosynthesis processes (Miller et al. 1995). Despite its important function in metabolic processes, iron is an enzyme cofactor that protects cells from oxidative damage, as well. Iron is needed in the greatest quantity among other micronutrients. The absence or deficiency of this element will cause a nutritional disorder in plants, resulting in poor yields and reduced nutritional quality. However, besides having benefits in living organisms, iron also has toxic properties (Connolly and Guerinot 2002; Morrissey and Guerinot 2009).

According to Farlex (2005), iron is included among heavy metal elements causing environmental pollutants. The toxicity of this element creates significant ecological, nutritional, evolutionary, and environmental problems. A high concentration of heavy metals in the soil will lead to several agricultural issues. For instance, it will disturb the uptake of essential mineral nutrients by plants (Clarkson and Luttge 1989). In addition, their accumulation in toxic concentrations will obstruct several metabolic processes and interfere with plant cell and tissue development (Rout and Sahoo 2015). Furthermore, it can induce several abnormal growth conditions, yield decrease, and death of the plant (Audebert and Fofana 2009; Chérif et al. 2009).
Iron toxicity is a widespread nutrient disorder affecting rice cultivation in most tropical regions. It is major abiotic stress that limits rice production not only in lowland but also upland cultivation areas (Müller et al. 2015; Rout and Sahoo 2015). Excessive amounts of iron are predominantly found in acidic soil, which is abundant throughout the world, including Indonesia (Notohadiprawiro 1989; von Uexküll and Mutert 1995). Approximately 50\% of arable lands globally consist of acidic soils, characterized by low $\mathrm{pH}$, low cation exchange capacity (CEC) and active iron (easily reducible iron), as well as low to moderately high in organic matter (Van Wambeke 1992; Sahrawat 2005). This condition implies that most agricultural production faces the problem of iron toxicity.

Recommended treatments to overcome iron toxicity issues are soil drainage, balanced fertilization to prevent nutrient deficiency, and soil $\mathrm{pH}$ increases by lime application or other alkaline materials. However, the use of tolerant cultivars is considered the most affordable and effective approach for improving rice productivity in affected areas. In vitro culture using somaclonal variation and in vitro selection is one of the typically advised approaches for developing new germplasm with improved character (Sakthivelu et al. 2008; Rai et al. 2011). This method is considerably more efficient compared to conventional or transgenic breeding programs. The technique has been applied in several rice breeding programs for abiotic stress tolerance characteristics, such as 
drought (Wani et al. 2010), salinity (Shankdar et al. 2000), aluminum toxicity (Roy and Mandal 2005), and iron (Rout 2015). In addition, the in vitro selection will minimize the environmental variations and apply homogeneity of stress treatment. The simplicity of such manipulations enables to studying large plant populations and stress treatments in a limited space and short period (Sakthivelu et al. 2008) owing to controlled, defined nutrient media conditions.

In this paper, we reported the development of iron tolerance character employing East Kalimantan local rice cultivars through somaclonal variation induction and in vitro selection. The response of East Kalimantan rice somatic embryos against abiotic stresses has never been evaluated before. This study will be an important preliminary work for the improvement of tolerance character against abiotic stress in local rice cultivars for the utilization of marginal land as agricultural conversion areas.

\section{MATERIALS AND METHODS}

\section{Plant materials}

The plant materials used in this study were four local upland rice cultivars from East Kalimantan, namely Serai Gunung (SG), Gedagai (GD), Mayas Pancing (MP), and Siam (SM). The cultivars are known as superior local rice cultivars owing to good grain quality in terms of taste characteristics.

\section{Somatic embryos production}

Somatic embryos were produced using mature rice seeds (Nurhasanah et al. 2018). The seeds derived from a physiologically mature rice grain were selected with the criteria free from pests and diseases while ensuring uniformity with respect to grain size. The rice seeds were sterilized by cleansing it first using detergent, and then rinsed with distilled water. The caryopsis was taken out by removing the lemma and palea manually. In a Laminar Air Flow Cabinet (LAFC), the caryopsis was sterilized by immersing in $70 \%$ alcohol solution for 1-2 minutes, followed by $30 \%$ of sodium hypochlorite for 15 minutes, and $10 \%$ sodium hypochlorite for 5 minutes. Subsequently, explants were washed with sterile distilled water twice for 3-5 minutes and drained on a sterile filter paper. The sterilized explants were inoculated on the callus induction media of solid Murashige and Skoog (MS) containing 30 g. $\mathrm{L}^{-1}$ sucrose and supplemented with $1 \mathrm{mg} . \mathrm{L}^{-1} 2,4$ Dichlorophenoxy acetic acid (2,4-D) and $0.5 \mathrm{mg} . \mathrm{L}^{-1}$ Benzylaminopurine (BAP). Explants then were incubated under dark conditions $\left(25 \pm 2^{\circ} \mathrm{C}\right)$. The somatic embryos derived from the scutellar tissue layer of mature rice seeds having high-quality callus were further used for in vitro iron selection.

\section{Media preparation and stress condition}

The basic media for iron stress was liquid MS media (without iron source substance) containing $30 \mathrm{~g}$ g. $\mathrm{L}^{-1}$ sucrose. The media were supplemented with the same growth regulation substances as somatic embryo production media, i.e., $1 \mathrm{mg} . \mathrm{L}^{-1} 2.4-\mathrm{D}$ and $0.5 \mathrm{mg} . \mathrm{L}^{-1} \mathrm{BAP}$. Five levels of iron concentrations were used: $0 ; 27.8 ; 55.6$; 83.4, and $111.2 \mathrm{mg} . \mathrm{L}^{-1}$ of $\mathrm{FeSO}_{4} .7 \mathrm{H}_{2} \mathrm{O}$.

In this study, the treatment consisted of an absence of iron source (without $\mathrm{FeSO}_{4} .7 \mathrm{H}_{2} \mathrm{O}$ ); normal iron concentration which is needed for plant tissue culture in MS media (27.8 mg.L $\mathrm{L}^{-1}$ of $\mathrm{FeSO}_{4} .7 \mathrm{H}_{2} \mathrm{O}$ ) (Murashige and Skoog, 1962; Sokolov et al. 2015); and the excess iron concentrations consisted of two, three and four folds of that at the normal concentration $\left(55.6 ; 83.4\right.$; and $111.2 \mathrm{mg} . \mathrm{L}^{-1}$ of $\mathrm{FeSO}_{4} .7 \mathrm{H}_{2} \mathrm{O}$ ) which are the toxic concentrations of iron (Noor et al. 2012; Nurhasanah et al. 2019).

The media $\mathrm{pH}$ was adjusted to 4.00 for the ironcontaining media and 5.8 for the zero iron concentration (without iron source). The liquid media then were poured into small culture bottles. Each culture vial $(100 \mathrm{~mL})$ contained $10 \mathrm{~mL}$ of iron-selection media. A piece of raft foam $(0.75 \mathrm{~cm}$ in height $)$ was placed at each bottle base covered with a single layer of filter paper to prevent explants from drowning. Sterilization of the media made use of standard heat sterilization procedures with autoclaving at $120^{\circ} \mathrm{C}, 1.5 \mathrm{~kg} . \mathrm{cm}^{-2}$ for 30 minutes.

Explants employed in this experiment were one-monthold somatic embryos having a yellowish color and friable structure. The embryonic callus (EC) clumps of a $0.5 \mathrm{~cm}$ diameter were laid on the top of the filter paper and grown on the iron-selection medium for a month. The cultures were incubated under light conditions (24-hour photoperiod) at $25 \pm 2^{\circ} \mathrm{C}$. Seven replications were carried out for each treatment, and each experimental unit consisted of four clumps of rice EC.

\section{Regeneration}

After a month on the iron-selection media, the EC clumps were subsequently transferred to germination media (MS solid medium containing 30 g.L $\mathrm{L}^{-1}$ sucrose and 2 g. $\mathrm{L}^{-1}$ activated charcoal) for a month. Thereafter, the clumps were grown on the regeneration media, MS solid medium containing 30 g. $\mathrm{L}^{-1}$ sucrose supplemented with $1 \mathrm{mg} . \mathrm{L}^{-1}$ BAP. All of these treatments were carried out under light conditions (24-hour photoperiod) at $25 \pm 2^{\circ} \mathrm{C}$.

\section{Data collection and analysis}

EC development was evaluated after iron stress treatment. The regeneration ability of EC was also observed. The qualitative data were analyzed using analysis of variance, and significant differences among treatment means were calculated by Duncan's Multiple Range Test at a probability level of 0.05 .

\section{RESULTS AND DISCUSSION}

\section{Effect of iron stress on EC survival}

Statistically, plant genotype had a significant effect on EC survival against iron and acidity stress. The survival ability of EC on the selection media was different for every plant genotype. Among the four genotypes, Mayas Pancing had the highest survival number of EC for each iron stress concentration level, and significantly differed to other local 
rice genotypes (Table 1). On the other hand, EC of the Serai Gunung cultivar had the lowest percentage of survival on the treatment. It was assumed that Mayas Pancing has a better tolerance to iron and acidity stress compared to other genotypes. The role of genotype in iron tolerance was also reported by Rout and Sahoo (2015). Different iron tolerance levels were observed in 51 rice cultivars with respect to in vitro germination. The role of different enzyme activities regarding toxicity and iron deficiency in various plant genotypes is proposed as the reason (Rout et al. 2014; Priyardisini et al. 2015).

The survival of EC was significantly influenced by the iron concentration. In general, the higher the concentration of iron, the less the EC survival. The highest EC survival was observed in the presence of $27.8 \mathrm{mg} . \mathrm{L}^{-1} \mathrm{FeSO}_{4} .7 \mathrm{H}_{2} \mathrm{O}$, in which a normal concentration of iron needed by plants with respect to MS media composition (Murashige and Skoog 1962). EC survival was lower in the absence of an iron source in the selection media. It was even lower than the EC survival in the presence of two folds of normal iron concentration $\left(55.6 \mathrm{mg}\right.$. L ${ }^{-1} \mathrm{FeSO}_{4} .7 \mathrm{H}_{2} \mathrm{O}$ ). This means that the absence of iron in the growth media could interfere with cellular development and decrease growth performance.

The absence or deficiency condition of iron had a significant effect on plant metabolism. Deficiency of iron in plants increases the expression of various metabolic enzymes and may cause dramatic changes in carbon metabolism along with repression of photosynthetic enzymes (Thimm et al. 2001). The absence of iron in cell culture inhibits cell proliferation, and further, cells stop growing and eventually die. However, the impact of iron deficiency is not the same for every plant species. According to Wheeler et al. (1985), monocotyledonous species were more tolerant of iron than dicotyledonous species. Grasses were reported to have different mechanisms addressing iron deficiency compared to nongrasses. Among other grasses, rice is more tolerant to iron deficiency (Walker and Connolly 2008). This might be the reason for more than $50 \%$ EC survival in the absence of iron in the selection medium. A low number of potato calli survival (60-80\%) was observed in a study conducted by Boamponsem et al. (2017) in an absence or deficiency condition of iron. The calli were chlorotic or bleached and even necrotic on medium supplemented with 0 to $5 \mu \mathrm{M} \mathrm{Fe}$.

Table 1. Effect of Fe concentration and plant genotypes on the percentage of EC survival (\%)

\begin{tabular}{lccccc}
\hline \multirow{2}{*}{$\begin{array}{c}\text { FeSO } \\
\left(\mathbf{m g L}_{4} \mathbf{. 1}\right)\end{array}$} & SG & MP & GD & SM & \multirow{2}{*}{ Mean } \\
\cline { 2 - 5 } & 64.3 & 78.6 & 57.1 & 75.0 & $68.8^{\mathrm{A}}$ \\
27.8 & 78.6 & 92.9 & 85.7 & 78.6 & $83.9^{\mathrm{B}}$ \\
55.6 & 71.4 & 89.3 & 78.6 & 64.3 & $75.9^{\mathrm{A}}$ \\
83.4 & 42.9 & 57.1 & 85.7 & 64.3 & $62.5^{\mathrm{A}}$ \\
111.2 & 53.6 & 78.6 & 67.9 & 53.6 & $63.4^{\mathrm{A}}$ \\
\hline Mean & $62.1^{\mathrm{a}}$ & $79.3^{\mathrm{b}}$ & $75.0^{\mathrm{a}}$ & $67.1^{\mathrm{a}}$ & \\
\hline
\end{tabular}

Note: SG: Serai Gunung; MP: Mayas Pancing; GD: Gedagai; SM: Siam. Different lowercase and capital letters show significant differences in the same row and column respectively, according to DMRT at $\alpha=0.05$
Based on variance analysis, there was no significant interaction between genotypes and iron stress treatment. This implies that the iron stress treatment affected EC survival of all genotypes with a similar pattern. The rise in iron concentration reduced callus survival abilities in most genotypes. The presence of three and four fold of the normal iron concentration (83.6 and $111.2 \mathrm{mg}$. $\mathrm{L}^{-1}$ $\mathrm{FeSO}_{4} \cdot 7 \mathrm{H}_{2} \mathrm{O}$, respectively) generally led to the lowest percentage of EC survival for the four local rice cultivars. Presumably, it was the toxic level of iron. According to Noor et al (2012), $50 \mathrm{mg}$. $\mathrm{L}^{-1}$ is already a mild toxic iron concentration for rice seedling. Based on our previous study, $100 \mathrm{mg}$. $\mathrm{L}^{-1}$ of $\mathrm{FeSO}_{4} \cdot 7 \mathrm{H}_{2} \mathrm{O}$ is a toxic concentration reducing plant growth significantly, especially in the sensitive genotypes (Nurhasanah et al. 2019).

As micronutrients, iron is required by plants in smaller amounts than primary or secondary macronutrients. A high iron level will cause toxicity to the cells. It disturbs plant tissues and cell development (Rout and Sahoo 2015) owing to the disruption of several metabolic processes in cells. The surviving EC at toxic levels of iron was the tolerant calli. In the work presented herein, the proportion of tolerant calli that grow normally at the highest concentration of iron varied from 53.6 to $78.6 \%$ depending on plant genotype.

\section{EC response during in vitro stress condition}

High-quality EC, having a creamy white color and friable structure, thereby indicating their embryogenic capacity (Kumari et al. 2006), were used as explant sources in this study to evaluate their response against iron stress. However, the EC had differential responses under stress conditions. Their responses were observed based on visual color change. The EC maintained a yellowish-white or transformed into a green or brown color on the ironselection media (Figure 1). Most of the EC had a yellowish-white or creamish colour followed by brown and green (Table 2).

Callus color refers to the visual appearance of a callus. It is an indication of whether a callus is healthy and good growing or in a degenerative. In this study, robustly growing EC was observed with creamish and green colors. The calli were larger in size, exhibiting the proliferative ability of the cells. There was variation in the number of creamish and green colored calli at the different levels of iron concentration and genotypes. Green-colored calli were not found in abundance in the absence of iron for the Serai Gunung, Mayas Pancing, and Gedagai cultivars. According to Rout and Sahoo (2015), iron deficiency reduces chlorophyll production as iron is a constituent of several enzymes and certain pigments. Although iron is not used in the synthesis of chlorophyll, it is essential for its formation. Interestingly, there was no EC of the Siam cultivar that changed into the green color (Table 2), indicating the role of genetic factors in this case.

Under light conditions, callus having a green color could develop based on the development of chloroplastids, plastids containing chlorophylls, in the cells of callus tissue. In this study, the explant source for EC production was mature rice seeds, which are non-photosynthetic 
tissues, featuring smaller amounts of chloroplast lipids than photosynthetic green tissues, such as leaves. The green color changes in the EC demonstrated the rise in chloroplast lipids accompanied by increases of chlorophyll content in the callus (Matsuzaki 1984). Cells containing chloroplasts are a type of differentiated cells commonly found in callus or cell cultures. Chloroplast formation is also a sign that the cells undergo morphogenesis, wherein new shoots might emerge from the green spots of the callus (George et al. 2008). A high ratio promoted morphogenetic callus proliferation in compact callus with green color and was observed in a study conducted by Maureen and Pau (1990), the green callus has greater organogenic potential compared with other calli.

EC having a brown color was degenerated, exhibiting declining growth. The robust growing calli initially have a yellowish colour that changes into brown then black, finally became dying on the selection media (Figure 1b). The symptom of browning represents the physiological decline of the cells. Histochemical analysis showed that the brown calli synthesize, excrete, and accumulate high amount of phenolic compounds (Laukkanen 2000; He et al 2009). The highest number of browning calli was observed in the cases of three and four folds of normal iron concentration (Table 2), the toxic concentration of iron for the cells. On the other hand, there were several browning calli that became tolerant in the last stress duration. The calli proliferated and regenerated new tolerant cells, producing either yellowish or green calli (Figure 2).

\section{Regeneration of iron-tolerant callus}

Under stress conditions, EC was recovered in MS media containing activated charcoal to absorb growth regulator residue from the previous treatment. To induce plant regeneration, EC were then transferred to BAP- supplemented media. In the regeneration media, the EC exhibited different regenerative potential, and some of them could differentiate forming shoots or roots, but the rest formed secondary somatic cells. Most of the regenerative EC produced roots rather than shoots (Table 3 ). However, the number highly depended on genotype. Root-regenerating explants were frequently observed with the Mayas Pancing and Gedagai cultivars, of which both genotypes yielded neither shoots nor plantlets.

Cells forming roots as initial differentiation are usually not expected in tissue cultures. This is because there will be no shoots developing in the rooting cells. In this study, none of the rooting callus produced any shoots, and the cells further degenerated, beginning to brown and then die. According to Narayanaswamy (1994), callus producing roots will never differentiate into shoots because shoot morphogenesis is terminated with the formation of roots within a callus. Hence, the prospect of plantlet production from callus with roots is not feasible. On the contrary, it is easy to induce root development in shooting cells. The development of shoots and roots in tissue culture is affected by cytokinin and auxin concentration ratios (Pernisova et al. 2009; Sugimoto et al. 2011). A high ratio of auxin to cytokinin leads to the initiation of roots, whereas a low ratio results in the development of shoots. In this study, exogenous plant growth hormones were equally applied for each genotype. Therefore, a different response in terms of plant regeneration should be because of the difference in endogenous hormones, thereby demonstrating the role of plant genetics. In addition, several genes have been described to be involved in shoot or root induction during plant cell regeneration (Che et al. 2006; Liu et al. 2018). In support of previous studies, the role of genotypes was clearly observed in the regeneration ability of the EC from East Kalimantan rice cultivars.

Table 2. EC colour change according to iron stress concentration (\%)

\begin{tabular}{|c|c|c|c|c|c|c|c|c|c|c|c|c|}
\hline \multirow{2}{*}{$\begin{array}{c}\mathrm{FeSO}_{4.7 \mathrm{H}^{2} \mathrm{O}} \\
\mathrm{mgL}^{-1}\end{array}$} & \multicolumn{3}{|c|}{ SG } & \multicolumn{3}{|c|}{ MP } & \multicolumn{3}{|c|}{ GD } & \multicolumn{3}{|c|}{ SM } \\
\hline & Cream & Green & Brown & Cream & Green & Brown & Cream & Green & Brown & Cream & Green & Brown \\
\hline 0 & 60.71 & 3.57 & 35.71 & 75.00 & 3.57 & 21.43 & 50.00 & 7.14 & 42.86 & 75.00 & 0.00 & 25.00 \\
\hline 27.8 & 64.29 & 14.29 & 21.43 & 57.14 & 35.71 & 7.14 & 64.29 & 21.43 & 14.29 & 78.57 & 0.00 & 21.43 \\
\hline 55.6 & 50.00 & 21.43 & 28.57 & 71.43 & 17.86 & 10.71 & 46.43 & 32.14 & 21.43 & 64.29 & 0.00 & 35.71 \\
\hline 83.4 & 39.29 & 3.57 & 57.14 & 46.43 & 10.71 & 42.86 & 78.57 & 7.14 & 14.29 & 64.29 & 0.00 & 35.71 \\
\hline 111.2 & 46.43 & 7.14 & 46.43 & 57.14 & 21.43 & 21.43 & 39.29 & 28.57 & 32.14 & 53.57 & 0.00 & 46.43 \\
\hline Mean & 52.14 & 10.00 & 37.86 & 61.43 & 17.86 & 20.71 & 55.71 & 19.29 & 25.00 & 67.14 & 0.00 & 24.29 \\
\hline
\end{tabular}

Note: SG: Serai Gunung; MP: Mayas Pancing; GD: Gedagai; SM: Siam

Table 3. Regeneration of EC in BAP-supplemented media (\%)

\begin{tabular}{ccccccccc}
\hline $\begin{array}{c}\text { FeSO4.7H2O } \\
\left(\text { mgL }^{-1}\right)\end{array}$ & \multicolumn{2}{c}{ SG } & \multicolumn{2}{c}{ MP } & \multicolumn{3}{c}{ GD } & \multicolumn{2}{c}{ SM } \\
\cline { 2 - 9 } & Root & Plantlet & Root & Plantlet & Root & Plantlet & Root & Plantlet \\
\hline $\mathbf{0}$ & 0.00 & 0.00 & 28.57 & 0.00 & 25.00 & 0.00 & 0.00 & 0.00 \\
$\mathbf{2 7 . 8}$ & 0.00 & 0.00 & 75.00 & 0.00 & 67.86 & 0.00 & 0.00 & 0.00 \\
$\mathbf{5 5 . 6}$ & 0.00 & 0.00 & 60.71 & 0.00 & 46.43 & 0.00 & 0.00 & 0.00 \\
$\mathbf{8 3 . 4}$ & 10.71 & $3.57^{\mathrm{a}}$ & 46.43 & 0.00 & 32.14 & 0.00 & 0.00 & 0.00 \\
$\mathbf{1 1 1 . 2}$ & 7.14 & 0.00 & 92.86 & 0.00 & 67.86 & 0.00 & 3.57 & $3.57^{\mathrm{b}}$ \\
\hline
\end{tabular}

Note: SG: Serai Gunung; MP: Mayas Pancing; GD: Gedagai; SM: Siam; ${ }^{a}$ Producing four plantlets; ${ }^{\text {}}$ Producing six plantlets 

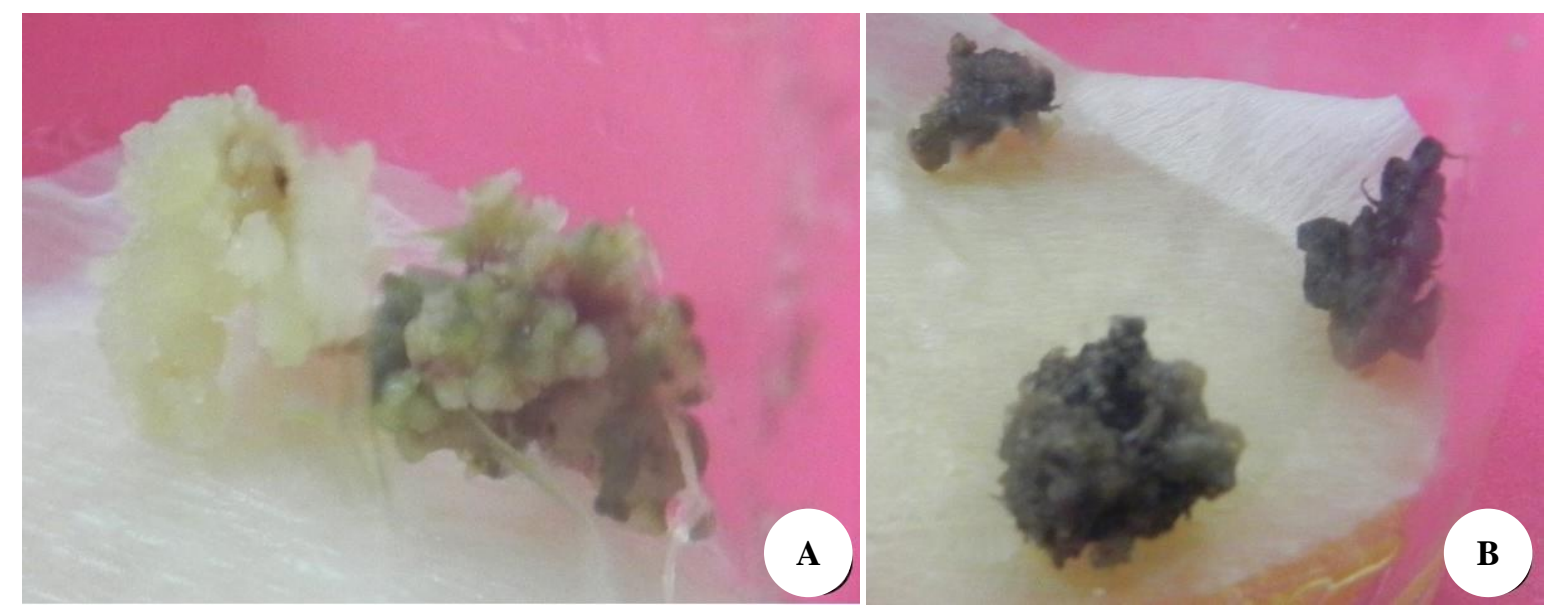

Figure 1. EC color change according to stress condition; A. Yellowish and green callus; B. Browning and black callus

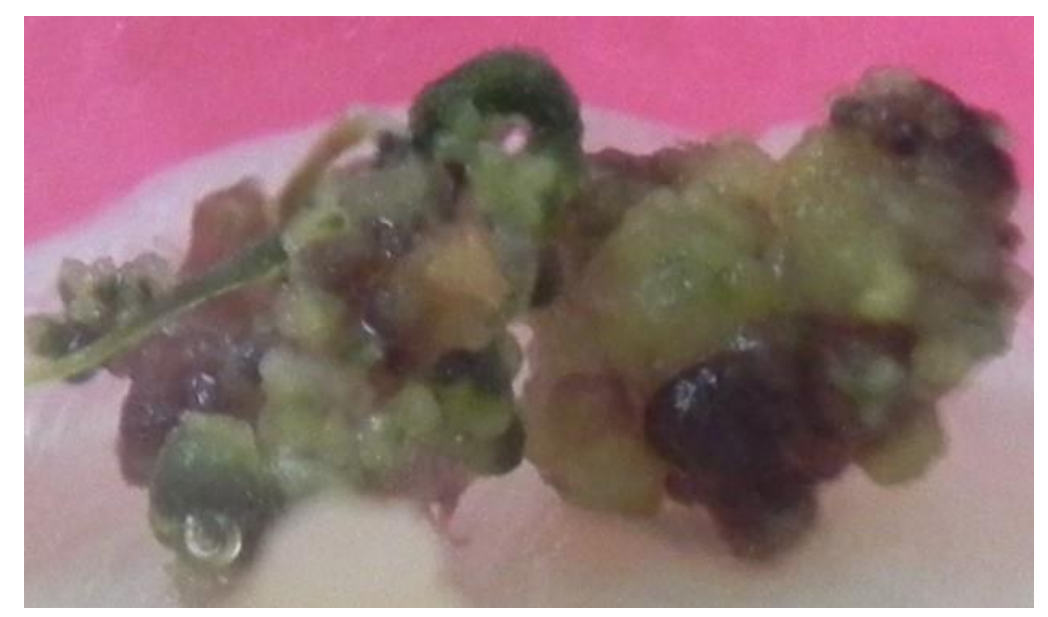

Figure 2. Browning calli producing new tolerant cells having either a yellowish or green color
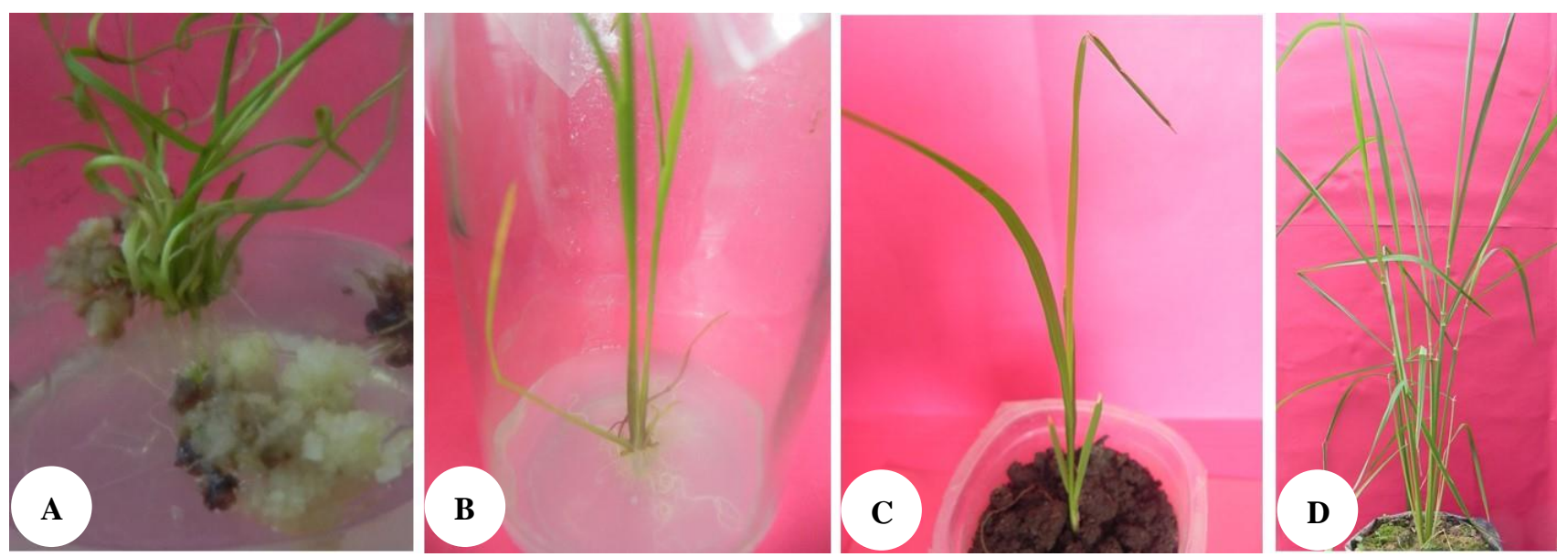

Figure 3. A. Plantlet regeneration; B. Plantlet in rooting medium; C. Acclimatization; D. Plant growth in the greenhouse (two-months old) 
Plantlets were only produced by embryonic clumps from Serai Gunung and Siam (Figure 3), which were the rarest root-regenerating cultivars (Table 3 ). Both genotypes resulted in four and six plantlets yielded from EC tolerant to toxic iron concentration (three and four folds of normal iron concentration). The plantlet regeneration efficiency was roughly 14 and $21 \%$ for Serai Gunung and Siam, respectively. The low plant regeneration ability in this work was suspected to be based on the genetic background of the local rice cultivars and in vitro stress conditions. Several studies have reported genotype-dependent effects of rice somatic embryo regeneration (Peng and Hodges 1988; Hoque and Mansfield 2004; Niroula et al. 2005).

Variation was not only exhibited between subspecies of indica and japonica (Abe and Fustsuhara 1986), but also among the indica rice cultivars as observed in this study. In our previous study, low regeneration ability was also noticed in the anther culture using the local rice genotypes (Nurhasanah et al. 2015; Nurhasanah et al. 2016). Moreover, the drown status of the explants basal part in the liquid medium under stress conditions might also influence their regeneration ability. The drown cells will experience poor aeration problems, resulting in impeded gas exchange and interfering with cell growth and development (Jackson 2005).

Interestingly the genotypes producing plantlets had the lowest green EC during in vitro selection (Table 2). The Siam cultivar did not even yield green EC during in vitro selection. The green color of EC, which was frequently observed in Mayas Pancing and Gedagai cultivars did not further differentiate into forming shoots or plantlets. The cells tended to form roots rather than shoots in our case. It has been explained that chloroplast formation in the green cells is a sign that the cells differentiate and undergo morphogenesis (George et al. 2008). However, the differentiation direction not only leads to form shoots, but possibly roots.

In conclusion, the deficiency and toxicity status of iron influences plant cell growth and development. The absence of iron in growth media resulted in lower EC survival. On the other hand, the toxic concentration of iron also significantly diminishes the proportion of EC survival. The tolerance of iron toxicity varied across different rice genotypes. The role of genotype was also clearly observed in terms of regeneration ability of EC. The putative tolerant plantlets could be regenerated from EC tolerant to toxic iron concentrations for the responsive genotypes. Further studies are necessary to evaluate the tolerance level of the putative iron-tolerant plants through the recurrent selection of $\mathrm{R}_{1}$ or $\mathrm{R}_{2}$ generation for the establishment of iron-tolerant rice cultivars.

\section{ACKNOWLEDGEMENTS}

This study was financed by IDB 4in1 project 2017 (399/UN17.11/PL/2017), to which the authors are highly indebted.

\section{REFERENCES}

Abe T, Futsuhara Y. 1986. Genotypic variability for callus formation and plant regeneration in rice (Oryza sativa L). Theor Appl Genet 72: 310 .

Audebert A, Fofana M. 2009. Rice yield gap due to iron toxicity in West Africa. J Agron Crop Sci 195 (1): 66-76.

Boamponsem GA, Leung DWM, Lister C. 2017. Insights into resistance to Fe deficiency stress from a comparative study of in vitro-selected novel Fe-efficient and Fe-inefficient potato plants. Front Plant Sci 8: $1-13$.

Che P, Lall S, Nettleton D, Howell SH. 2006. Gene expression programs during shoot, root, and callus development in Arabidopsis tissue culture. Plant Physiol 141: 620-637.

Chérif M, Audebert A, Fofana M, Zouzou M. 2009. Evaluation of iron toxicity on lowland irrigated rice in West Africa. Tropicultura 27: 1970-1975.

Clarkson DT, Luttge U. 1989. Mineral nutrition, divalent cations, transport and compartmentalization. Progr Bot 51: 93-112.

Connolly EL, Guerinot ML. 2002. Iron stress in plants. Genome Biol 3 (8): $1-4$.

de Alcantara GB, Dibax R, de Oliveira RA, Filho JCB, Daros E. 2014. Plant regeneration and histological study of the somatic embryogenesis of sugarcane, Saccharum spp. cultivars RB855156 and RB72454. Acta Scientiarum Agronomy 36 (1): 63-72.

George EF, Hall MA, De Klerk GJ. 2008. Plant Propagation by Tissue Culture, Volume 1 The Background. Springer, Netherlands.

He Y, Guo X, Lu R, Niu B, Pasapula V, Hou P, Cai F, Xu Y, Chen F. 2009. Changes in morphology and biochemical indices in browning callus derived from Jatropha curcas hypocotyls. Plant Cell Tiss Org Cult 98 (1): 11-17.

Hoque ME, Mansfield JW. 2004. Effect of genotype and explant age on callus induction and subsequent plant regeneration from root-derived callus of Indica rice genotypes. Plant Cell Tiss Org Cult 78: 217-223.

Jackson MB. 2005. Aeration stress in plant tissue cultures. In: HvoslefEide AK, Preil W, editors, Liquid Culture Systems for in vitro Plant Propagation. Springer, Netherlands.

Laukkanen H, Häggman H, Kontunen-Soppela S, Hohtola A. 1999. Tissue browning of in vitro cultures of Scots pine, role of peroxidase and polyphenol oxidase. Physiologia Plantarum 106: 337-343.

Liu J, Hu X, Qin P, Prasad K, Hu Y, Xu L. 2018. The WOX11-LBD16 pathway promotes pluripotency acquisition in callus cells during de novo shoot regeneration in tissue culture. Plant Cell Physiol 59 (4): 734-743.

Matsuzaki T, Koiwai A, Nagao T, Sato F, Yamada Y. 1984. Lipid compositions of photomixotrophic green calluses and chlorophyll deficient leaves of tobacco. Agric Biol Chem 48 (7): 1699-1606.

Maureen M, Pau HM. 1990. Comparison of 2, 4-D and picloram for selection of long-term totipotent green callus cultures of sugarcane. Plant Cell, Tissue and Organ Culture 20 (3): 157-163.

Miller GW, Huang IJ, Welkie GW, Pushnik JC. 1995. Function of iron in plants with special emphasis on chloroplasts and photosynthetic activity. In: Abadía J, editor, Iron Nutrition in Soils and Plants Developments in Plant and Soil Sciences, Vol 59. Springer, Dordrecht.

Morrissey J, Guerinot ML. 2009. Iron uptake and transport in plants: The good, the bad, and the ionome. Chem Rev 109 (10): 4553-4567.

Müller C, Kuki KN, Pinheiro DT, de Souza LR, Silva AIS, Loureiro ME, Oliva MA, Almeida AM. 2015. Differential physiological responses in rice upon exposure to excess distinct iron forms. Plant Soil 391: 123-138.

Murashige T, Skoog F. 1962. A revised medium for rapid growth and bioassays with tobacco tissue cultures. Physiologia Plantarum 15 (3): 473-497.

Narayanaswamy S. 1994. Plant Cell and Tissue Culture. 9th reprint. Tata McGraw-Hill Education, New Delhi.

Niroula RK, Sah BP, Bimb HP, Nayak S. 2005. Effect of genotype and culture media on callus induction and plant regeneration from matured rice grain culture. J Inst Agric Anim Sci 26: 21-26.

Noor A, Lubis I, Ghulamahdi M, Chozin MA, Anwar K, Wirnas D. 2012. Effect of iron concentration in the nutrient solution to the symptoms of iron toxicity and growth of rice plants. J Agron Indonesia 40 (2): 91-98. 
Notohadiprawiro T. 1989. Farming acid mineral soils for food crops, an Indonesian experience. In: Craswell ET, Pushparajah E (eds.) Management of Acid Soils in the Humid Tropics of Asia. Australian Centre for International Agricultural Research, Canberra.

Nurhasanah, Lestari HS, Sunaryo W. 2019. The response of East Kalimantan, Indonesia local rice cultivars against iron stress. Biodiversitas 20 (1): 273-282.

Nurhasanah, Pratama AN, Rusdiansyah, Sunaryo W. 2015. Effect of genotype and developmental stage of pollen on the success of anther culture of local upland rice cultivars from East Kalimantan. Asian J Microbiol Biotechnol Environ Sci 17 (2): 329-340.

Nurhasanah, Pratama AN, Sunaryo W. 2016. Anther culture of local upland rice cultivars from East Kalimantan, effect of panicle cold pretreatment and putrescine enriched medium. Biodiversitas 17 (1): 14853.

Nurhasanah, Ramita, Bambang S, Sunaryo W. 2018. Somatic embryogenesis of East Kalimantan local upland rice cultivars. IOP conf Ser Earth Environ Sci 144: 012031. DOI: .10.1088/1755$1315 / 144 / 1 / 012031$

Peng J, Hodges TK. 1989. Genetic analysis of plant regeneration in rice (Oryza sativa L). In Vitro Cell Dev Biol 25 (1): 91-94.

Pernisová M, Klíma P, Horák J, Válková M, Malbeck J, Soucek S, Reichman P, Hoyerová K, Dubová J, Jiří F, Eva Z, Jan H. 2009. Cytokinins modulate auxin-induced organogenesis in plants via regulation of the auxin efflux. Proc Natl Acad Sci USA 106: 3609-14.

Priyadarsini A, Sahoo S, Rout GR. 2015. Study of in vitro selection and plant regeneration of Indica rice tolerant to iron. Intl J Agric Environ Biotechnol 8 (2): 285-93.

Rai MK, Kalia RK, Singh R, Gangola MP, Dhawan AK. 2011. Developing stress tolerant plants through in-vitro selection - An overview of the recent progress. Environ Exp Bot 71: 89-98.

Rout GR. 2015. Study of in vitro selection and plant regeneration of Indica rice tolerant to iron. International J Agriculture, Environment and Biotechnology 8 (2): 285-93.

Rout GR, Sahoo S. 2015. Role of iron in plant growth and metabolism. Reviews in Agricultural Science 3: 1-24.

Rout GR, Sahoo S, Das AB, Das SR. 2014. Screening of iron toxicity in rice genotypes on the basis of morphological, physiological and biochemical analysis. J Exp Biol Agric Sci 2 (6): 567-82.
Roy B, Mandal AB. 2005. Towards development of al-toxicity tolerant lines in indica rice by exploiting somaclonal variation. Euphytica 145: 221-27.

Sahrawat KL. 2005. Iron toxicity in wetland rice and the role of other nutrients. J Plant Nutr 27 (8): 1471-04.

Sakthivelu G, Akitha-Devi MK, Giridhar P, Rajasekharan T, Ravishankar GA, Nede T, Kosturkova G. 2008. Drought-induced alterations in growth, osmotic potential and in-vitro regeneration of soybean cultivars. General Appl Plant Physiol 34: 103-112.

Shankhdhar D, Shankhdhar S, Mani S, Pant RC. 2000. In vitro selection for salt tolerance in rice. Biologia Plantarum 43 (3): 477-480.

Sokolov RS, Atanassova BY, Iakimova ET. 2015. Influence of iron sources in the nutrient medium on in vitro shoot multiplication and rooting of magnolia and cherry plum. J Hortic Res 23 (2): 27-38.

Sugimoto K, Gordon SP, Meyerowitz, EM. 2011. Regeneration in plants and animals, dedifferentiation, transdifferentiation, or just differentiation? Trends Cell Biol 21: 212-218.

Thimm O, Essigmann B, Kloska S, Altmann T, Buckhout TJ. 2001. Response of Arabidopsis to iron deficiency stress as revealed by microarray analysis. Plant Physiol 127: 1030-1043.

Van Wambeke A. 1992. Soils of the Tropics, Properties and Appraisal. McGraw-Hill Inc., New York.

von Uexküll HR, Mutert E.1995. Global extent, development and economic impact of acid soils. In: Date RA, Grundon NJ, Raymet $\mathrm{GE}$, Probert ME, editors. Plant-Soil Interactions at Low $\mathrm{pH}$, Principles and Management. Kluwer Academic Publishers, Dordrecht, Netherlands.

Wani SH, Sofi PA, Gosal SS, Singh NB. 2010. In vitro screening of rice (Oryza Sativa L) callus for drought tolerance. Commun Biometr Crop Sci 5: 108-115.

Walker EL, Connolly EL. 2008. Time to pump iron: Iron-deficiencysignaling mechanisms of higher plants. Curr Opin Plant Biol 11: 53035 .

Wheeler BD, Al-Farraj MM, Cook RED. 1985. Iron toxicity to plants in base-rich wetlands, Comparative effects on the distribution and growth of Epilobium hirsutum L and Juncus subnodulosus Schrank. New Phytol 100: 653-669. 